\title{
Parrhesia and Clinical Practice: A Case Study of Dr. Esdaile's Mesmeric Hospital in Hooghly
}

\author{
Punnya Rajendran \\ Assistant Professor, Department of English Studies, Central University of Tamil Nadu. \\ Email: punnyarajendran@cutn.ac.in \\ ORCID: https://orcid.org/oooo-0oo2-6311-7383.
}

\begin{abstract}
This paper seeks to explore the complex negotiation between mesmerism (as unauthorised medical practice) and the State by analyzing the singular example of Dr. James E. Esdaile, a Scottish civil surgeon stationed in Hooghly, Calcutta, in the 1840-50s; one of the few known medical practitioners of mesmerism in colonial India. His diary titled Mesmerism in India, and its Practical Application in Surgery and Medicine contains a record of every patient who walked into Esdaile's clinic in Hooghly complaining of pain, the subsequent interaction that took place between the doctor and the patient, usually in the form of a simple sequence of questions and answers, and a description of the procedure by which the patient was treated. The documentation of Esdaile's controversial clinical practice offers several important insights into the practice of parrhesia (a theory of truth-telling proposed by Foucault) in conjunction with the practice of mesmerism as medicine. Within the annals of medical history, clinical egodocuments such as Esdaile's surgical diary exemplify the emergence of a difficult relationship between the historical subject and the desire to speak the truth. It reveals how a unique moment in colonial medical history becomes emblematic of a negative relationship with the parrhesiastic act.
\end{abstract}

Keywords: mesmerism, colonial medicine, parrhesia, Esdaile, surgical diary

\section{Introduction}
Dr. Fluder need be under no apprehension of an attack in the Mesmeric Magazine affecting him in the opinion of the profession. The journal only finds circulation among the class of imposters who record their doings in it.

-Medical Gazette, 1845.

When Franz Anton Mesmer announced to the world from Paris in 1778 that he had definitive proof of the existence of an invisible cosmic fluid which surrounded and passed through all living and non-being beings in the universe, many in the Western world were seduced (Pattie 1994). It was, after all, an age when scientists were being, for the first time, encouraged to deduce the shape of invisible natural forces based on whatever data was visible in the natural world. The ascribing of visible effects to invisible causes (based on animistic, vitalistic, and mechanistic theories) was a scientific practice which veered alternately in both right and wrong directions. As Robert Darnton wrote wryly about this period, Galvani was experimenting with animal electricity in Italy at the same time that Mesmer was using animal magnetism (also known as mesmerism) to cure hundreds of sick persons in France (Darnton 1970, 2-45).

(c) AesthetixMS 2021. This Open Access article is published under a Creative Commons Attribution Non-Commercial 4.0 International License (http://creativecommons.org/licenses/by-nc/4.o/), which permits non-commercial re-use, distribution, and reproduction in any medium, provided the original work is properly cited. For citation use the DOI. For commercial re-use, please contact editor@rupkatha.com. 
The rise and fall of mesmerism in parts of Western Europe, the United States, and England has been well-documented. Public demonstrations of mesmerism as well as unauthorized attempts to cure sick people using mesmerism were rampant in these societies during the 18th and 19th centuries. The aristocratic classes held private performances in their mansions, such as the novelist Charles Dickens who was reportedly great friends with Dr. Elliotson, the practitioner of mesmerism in England (see Willis \& Wynne 2006, 7) while the lower classes thronged the streets to watch these public performances and were routinely accused of desiring the gendered sexual thrill of watching an apparently nubile young woman turned into a listless puppet animated by a man on the stage (Lamont 2013). In the United States, at the same time, Edgar Allan Poe too was inspired to write his Gothic thrillers upon hearing news about mesmerism being practiced in various parts of the Western world. ${ }^{\mathrm{i}}$

Apart from the ways in which mesmerism unsettled the emerging demarcations between curative medicine and fantasy in the 18th century (the very idea of a "cure" is fantastically perceived by the observers of mesmeric practice), the radical political intellectuals of the time, especially in France, were drawn towards the Rousseau-ian strains in a theory of animal magnetism that advocated a return to lap of "Mother Nature." Medical science represented state power and the state's refusal to announce the validity of mesmerism as 'medicine proper' was attacked by people like Bergasse who spoke in the French Parliament against "that tyrannical medicine" which refused to consider alternatives (Armando \& Belhoste 2018). Reminiscent of contemporary debates that pit Western medicine against other curative systems of the world, Bergasse's declarations epitomize the relationship between mesmerism and the modality of truth-telling in front of the State in the 18th and the 19th centuries when, as Foucault points out, many of the modern institutions that definitively constructed the truths of this time period (such as germ theory and electromagnetism) were in the process of being born.

This paper seeks to explore the complex negotiation between mesmerism (as unauthorized medical practice) and the State by analyzing the singular example of Dr. James E. Esdaile, a Scottish civil surgeon stationed in Hooghly, Calcutta, in the 1840-50s; one of the few known practitioners of mesmerism in colonial India. ${ }^{\text {ii }}$ In 1846 , he wrote and published a surgical diary which quickly sunk into oblivion in spite of two reprints under slightly different titles. ${ }^{\text {iii }}$ He also published several articles in the Calcutta Medical Journal attesting to the success of his painless surgeries in Hooghly at the Imambarah Hospital and later at the short-lived Mesmeric Hospital, reiterating the curative and anaesthetic properties of mesmerism based on the empirical evidence of painless surgeries conducted on the bodies of native patients. Taking place in the faraway tropics, in a clinical practice that encompasses a spectrum of native patients, surgeons, and witnesses, the documentation of Esdaile's controversial clinical practice offers several important insights into the practice of parrhesia (a theory of truth-telling proposed by Foucault) in conjunction with the practice of mesmerism as medicine.

The diary titled Mesmerism in India, and its Practical Application in Surgery and Medicine runs into two hundred pages and contains meticulous logs of the allegedly pain-free surgeries Esdaile conducted under the influence of mesmerism on his native patients, mostly consisting of impoverished convicts (i.e. imprisoned wards of the government) suffering from various kinds of inflammatory diseases which were common in the tropics at the time such as filariasis and elephantiasis. The finished book, complete with lengthy declamations about the efficacy of the superior and divine science of mesmerism and doleful references to the medical community's disregard and ridicule for mesmerism as well as eloquent appeals for the greater good, falls into the genre of a philosophical 
or political treatise as much as it is a surgical diary and an important document of life-writing in the annals of colonial medicine in India.

The prose is interspersed liberally with clinical episodes. It contains a record of every patient who walked into Esdaile's clinic in Hooghly complaining of pain, the subsequent interaction that took place between the doctor and the patient, usually in the form of a simple sequence of questions and answers, and a description of the procedure by which the patient was treated. "There is a frankness," writes the editor of the Chicago edition in 1902, "an absence of art, about this book which makes its testimony [...] of double worth. No one may question the facts here recorded. They are FACTS, and they are recorded, as Truth should be, in simple speech" (Flower 1902, n.p.). In the opening pages of the diary, similarly, Esdaile declares that he is willing to pledge his "private and professional character" for the truth of Mesmerism if only he is allowed to speak about it. In February 1846, in a letter written to his father from Hooghly shortly after conducting his first few successful surgeries, Esdaile declares that he has not only introduced but "established, a new and powerful means of alleviating human suffering among the natives of Bengal” (Esdaile 1902, 8).

Consider Foucault's description in Discourse and Truth of parrhesia and its complicated relationship to the state and to civil society in the following passage.

$[\mathrm{P}]$ arrēsia is a certain verbal activity in which the speaker has a specific relation to truth through frankness, a certain relation to himself through danger, a certain relation to law through freedom and duty, and a certain relation to other people through critique (selfcritique or critique of other people). More precisely, it is a verbal activity in which the subject expresses his personal relation to truth and risks his life because he recognizes that telling the truth is his own duty, so as to improve or to help other people. (Foucault 2019, 45-6)

Thus far, the dominant narrative tone of the diary appears to exemplify the use of parrhesia, albeit a misguided one, in the bold and self-sabotaging dialogue it attempts to strike with the government, with the medical community, and with the public. Esdaile's statements are marked with a directness and a willingness to engender his own reputation in order to push forward an unalienable truth for the greater good of humanity. However, a closer examination is required of Esdaile's truthtelling function, both in the context of the future trajectory of Western medicine which will go on to spare no scientific validity for mesmerism as well as in the context of colonial Hooghly which is the theatre for Esdaile's surgeries.

\section{Faux-parrhesia: A Problem of Historicity}

In the diary, we find evidence of how Esdaile constructed an elaborate network of witnesses and testimonies inside his clinic_- "disinterested, honorable, and intelligent gentlemen" (Esdaile 1902, 56) who would record and attest what they saw and corroborate each other's testimonies. His relentless belief in the clinical method as the best possible evidence for what is essentially a fantastical phenomena (the idea that a monistic vital fluid that traverses the universe and can be manipulated by physicians to cure diseases) means that Esdaile relied entirely on the processes of showing and seeing.

Hoping for an incremental effect, Esdaile invited witnesses with abandon. The more the number of witnesses, the closer Esdaile believed he would come to a threshold point of empirical proof after which mesmerism will have to accepted simply because a certain number of people, whether or not they believed in mesmerism, saw it happen in front of their eyes. "I would have preferred the plain 
of Calcutta for my theatre, and all the inhabitants for spectators, if it had been possible" (Esdaile 1902, 56). Therefore, he offers long lists in his diary of the names of eminent persons who acted as witnesses for his surgeries. So strong is the tautology by which Esdaile fetishises the gaze (seeing equal to knowing) that at one point in his diary he declares that those who refuse to believe in mesmerism even after witnessing it with their own eyes are guilty of "irrational incredulity" (Esdaile $1902,21)$. The same opinion is echoed by the editor of the 1902 Chicago edition of Mesmerism in India who states that the evidence provided by Esdaile in his diary is so overwhelming "that incredulity seemed irrational" (Flower 1902, n.p.).

Esdaile was writing and practising at a time when the study of medicine was no longer physically confined within the walls of the university and nor was it imaginatively confined, as Foucault observes in The Birth of the Clinic, to "the old theory of sympathies [which] spoke a vocabulary of correspondences, vicinities, and homologies" (Foucault 1973; 2003, 3). Pre-modern theories of medicine thought about diseases (or a single entity Disease) and bodies as separate units; pathology had nothing to do with anatomy. Diseases were studied in books and then found on the body. Modern medicine was a rupture in this old-world paradigm, and the chief characteristics of the new medical practise was relentless observation of the patient by the doctor, accompanied by detailed verbal descriptions of what is visible.

Over a period of time, the modern clinical gaze reimagined disease as something that is not simply found on the body, but rather it was the body itself; a tissue transforming unfavourably due to an external irritant and then, upon being cured, returning to being healthy tissue again. As a result of this "exact superposition of the 'body' of the disease and the body of the sick man" (Foucault 3) as a result of the perfectly immanent new imagination that redefines the disease as nothing but an altered and undesirable state of human tissue, a "loquacious gaze" (Foucault xi) becomes the norm inside the clinic, a practice of identifying the truth by verbalising the visible.

The study of medicine shifts from the universities to the field hospitals, the jail hospitals, and the charity hospitals (where Esdaile conducted his surgeries), where diseases are studied on a case-bycase basis on the body of the patient until pathology dissolves into physiology or pathological anatomy, into an empiricist and positivist interest in endless observation and logging of accurate details. In other words, the old equation between cause and effect (the cause of the symptoms on the body is often described as 'forces' and attributed to atmospheric powers which are external to the body) dissipates as a result of the clinical turn. Diseases found on the body are no longer to mapped to anything outside of the body. The dichotomy between cause and effect disappears in the medical imagination.

In other words, mesmerism was a truth which would have had little difficulty in gaining public eligibility a hundred years before Esdaile. Several decades down the lane too, Esdaile's theory might have been acceptable under the more respectable para-scientific concept of hypnotism. Noting this misplacing of a truth-teller as a tragedy of sorts, Ernst comments that "if Esdaile had not doggedly insisted on the material existence of the animal fluid and had instead subscribed to the psychological concept of hypnotism, he may have more readily gained his profession's approval" (Ernst 1995, 1120). This points in the direction of such a historic miscalculation, a slippage in the discursive categories of Esdaile's practice which thwarted an otherwise meticulous follower of the Newtonian scientific method much revered and accepted in the 19th century.

It is evident to us today, with the benefit of historical hindsight alone, that Esdaile misinterprets the emerging clinical imagination of the 19th century by grasping its external form (the interaction between the doctor and the patient in the clinic based on observation and the collection of empirical data) and not its underlying philosophy which no longer believed in mapping the effect onto 
an extra-physiological cause. Convinced beyond doubt that the medical community will map the documented observable effects of mesmeric practice to the invisible force of animal magnetism, he proclaims at one point in the diary that "Nature is but a name for an effect, whose cause is God" (Esdaile 1902, 104).

This misinterpretation of clinical practice is the first problematic we can identify in the use of parrhesia in Esdaile's surgical diary; a discursive stutter in method. In fact, this begs us to consider an alternative reading of parrhesia within the context of Western medical history. Early on, in Discourse and Truth, Foucault wonders whether a parrhesiastic can be identified as one who believes he is speaking the truth or one who really is speaking the truth. Is it the epistemological content or the form of the "speech activity" that determines parrhesia? The answer offered by Foucault is in the following uncertain yet certain terms.

[T] he parrhesiast says what is true because he thinks that it is true, and he thinks that it is true because it is really true. Not only is the parrhesiast sincere, not only does he state his opinion frankly, but his opinion is also the truth. He says what he knows to be true. In parrēsia, there is a coincidence, an exact coincidence, between belief and truth. (Foucault 2019, 41-2)

The status of truth in the above passage is ambiguous. It would appear that only history can tell who were the real users of parrhesia and who were simple involved in idle "chattering" (Foucault 2019, 41). The critical valency of parrhesia is obviously not best spent in creating an account of true and false parrhesiastics. Therefore, to disqualify Esdaile's diary as an act of parrhesia on account of mesmerism being discredited conclusively later in history is not productive. In fact, a medical journal at the time denounces both mesmerism and homeopathy in one sentence; the latter is still widely practiced today along with naturopathy and various kinds of therapeutic hypnosis. ${ }^{\text {iv }}$ If anything, the epistemic integrity of the diary remains technically open-ended to this day, as by that extension, there is an entire order of such empirically grounded but theoretically weak proclamations in modern medical science which can unsettle the concept of parrhesia productively.

In this light, I propose that the use of parrhesia in Esdaile's diary exemplifies it as a speech activity that occurs when someone attempts to speak truth to power at a certain discursive juncture in history (marked in this case by a shift from a pre-modern to a clinical imagination) which necessarily scrambles the codes of representation employed by the speaker. Instead of the ancient Greek dichotomy between parrhesia and idle chatter, the age of positivism with its emphasis on observable facts and evidence results in the use of what I call the phenomenon of faux-parrhesia, which is based on a Cartesian abundance of evidence.

At one point in the preface to Natural and Mesmeric Clairvoyance (1852), Esdaile compares himself to Galileo, a historical figure who by any standards is a stellar example of the parrhesiastes. He cites a letter written by Galileo to Kepler about a professor of philosophy who refused to accept observable evidence through the telescope. The danger to Esdaile's reputation among his professional peers is likened to the threat of death faced by Galileo (Esdaile 1852, x). The definition and use of the category of faux-parrhesia lies in the perceived epistemological difference in status between the speech activity of Esdaile and Galileo.

Our intuitive identification of Galileo as the true parrhesic does not mean that Esdaile is an imposter in the annals of Western medical history. He exemplifies the historical indispensability of being wrong. It is by the extension of the same logic that many radical left revolutionaries in France and in England believed in the truth of animal magnetism at the time; it resembled a marginalised truth worth supporting for the sake of a better world. In fact, from Esdaile's reference to Napoleon- 
"Even Louis Napoleon has not yet prohibited the discussion of Mesmerism, like our dictators of the medical press" (Esdaile 1852, xii) — and from the support garnered by radical thinkers who equated the banning of mesmerism with state tyranny of the natural freedom of humankind, we may understand that there was considerable overlap between those who believed in mesmerism and those who believed in democratic ideals. Faux-parrhesia is marked by a compelling semblance of truth.

Thus, every parrhesiastes runs the risk not only of danger to life and reputation and public ridicule, as Foucault tells us, but also runs the risk of not being a parrhesiastes and never realising it, the risk of uttering the external structure of well-intended truth but misinterpreting the discursive foundations of what can be truth at any given point in time. So close was Esdaile to the actual use of parrhesia that his interactions with the imperial government in Hooghly (if not back at home in the West) are truly emblematic of what Foucault calls a parrhesiastic game that reinforces power relations between the speaker and the state; whereby franc-parler is a privilege given by the state to the speaker, an allowance and a temporary lifting of mortal risk that can be withdrawn at any moment (Foucault 2019, 54).

\section{"Permission to Prove the Truth": Medicine as Performance}

In Esdaile's case, this parrhesiastic "game" or "contract" becomes possible only in the backdrop of colonialism. In 1784, the Faculty of Medicine of Paris, sanctioned by the Parliament, ordained that any physician known to be following the doctrines of Franz Mesmer will be struck off the list of the Medical Society. In 1838, the Council of University College, London, in collaboration with the reputed medical journal Lancet pronounced a similar excommunication of Dr. Elliotson. ${ }^{\mathrm{v}}$ In Calcutta, however, Esdaile had the full support of Lord Dalhousie at one point. In fact, when Esdaile offered to give him "ocular demonstration" to solicit the support of the state, Lord Dalhousie reportedly responded with an exclamation "There can be no doubt whatever" and deemed evidence to be superfluous (Esdaile 1856, 25).

It would, therefore, appear as though Esdaile practised mesmerism with the knowledge and full cognisance of the government, or as the subtitle of one of his books indicate proudly- "with the sanction of the government" - a phrase which, in retrospect, appears within doubtful parenthesis on the cover of his 1856 book, for this "sanction" was fundamentally of a parrhesiastic variety. Sanction to prove mesmerism by conducting painless surgeries in state-owned hospitals was not necessarily a vote in support or approval of mesmerism by the state. The word "sanction" here means the permission to prove but under the shadow of cynicism and doubt, which makes for a very quixotic relationship between Esdaile and the Calcutta Presidency.

Esdaile frequently wrote articles about his surgeries in the Calcutta Medical Journal until at one point, the editor withdrew permission and began to disparage the practice in public. However, while the editor referred to Esdaile's native patients as a "set of hardened and determined imposters" he also noted at the same time that Esdaile's own honesty, his good intentions and genuine faith in his practise "could not be questioned" (Esdaile 1852, vii), consolidating once again Esdaile's image as a parrhesiastes even among the detractors at the time.

Similarly, the government first constituted a committee to observe Esdaile's practice and write a report about it. The committee's report was not favourable despite the fact that they couldn't identify any fraud in the spectacle of witnessing and testimonials that Esdaile arranged day after day in public. Subsequently, the government permits Esdaile who had until then been conducting his surgeries at the Jail Hospital to open a Mesmeric Hospital, with the caveat that all surgeries ought to be conducted in the presence of anyone who wished to see them. This hospital too, after a period 
of great activity, was shut down by the government, again without having detected any fraud in the process (Ernst 1114).

The ambivalent conditions on which sanction was given and later revoked, both by the government and by the editor of the Calcutta Medical Journal, brings us to the second problematic in this case study. If one might go so far as to racialise the use of parrhesia, it would appear from the Calcutta case study that the use of parrhesia was predicted on the availability of warm bodies in the form of native patients at the Jail Hospital in Hooghly. Esdaile's diary which is not only a medical journal but also an accidental document of colonial medical ethnography. It uses the diseased body of the native patient as both a speaking agent and as a passive object in an elaborate process of truthtelling in front of the state.

The general public, both cynics and believers, has always been fascinated with public demonstrations of mesmerism held in Europe and in the U.S. at the time, and these demonstrations were infamous for their sexualization of the female subjects who were mesmerized by male practitioners. However, none of these performances ever tried to strike up such a direct conversation with medical science and were content mostly to exist as sources of entertainment for the public. By contrast, as a result of Esdaile's relentless desire for parrhesia, the medical performances at the Mesmeric Hospital, centered around the native patient's body splayed on a gurney, aspire to the epistemic status of evidence and not just entertainment. Already, Esdaile's belief that seeing equalled believing introduced a performative value in the words spoken by the patient in front of witnesses, in the visible evidence of the absence and presence of pain on the body of the patient. As a result of the long history and natural affinity of mesmeric practice with the thrill of public performance, a tension emerges between the evidentiary and the performative in Esdaile's clinic.

At one point the Bengal Hurkaru made note of the crowds that thronged the Mesmeric Hospital to watch Esdaile's painless surgeries (W[ebb?] 1846, n.p.). In a spectatorial ensemble arranged like a Russian doll, Esdaile watched his patient, while a circle of invited guests watched them both, and they were in turn surrounded by a crowd of these unsolicited but desired native audience were also crude witnesses to the "respectable gentlemen." They were valued in sheer numbers rather than as credible individuals; 'groundlings' in some sense in this bizarre Hooghly theatre.

However, the fundamental difference between mesmerism as entertainment in Esdaile's medical practice in Hooghly and mesmerism as entertainment on a stage at a fair in Victorian England can be found in another excerpt that appears in the same Bengal Hurkaru. vi "Painless operations are becoming very common-place uninteresting affairs in the eyes of the Calcutta community,' writes the Hukuru correspondent, wryly. "Our good public having supped full of wonders of this sort, begins to think that there is nothing worth seeing in them at all" (Painless Operations 1848, 3). The same article proceeds to make a disparaging reference to these "everlasting painless operations, of which everyone is getting heartily bored."

The spectatorial value of mesmerism in public (which other practitioners such as Elliotson had used to conduct gripping performances tailor-made for the specific audiences) seemed to have been completely lost on Esdaile. Rightly so, the correspondent notes that the Mesmeric Hospital was also instituted for public entertainment and unless there is some variety in the "same melodrama" they will lose interest. The very same article, however, proceeds to narrate the example of a very successful surgical procedure conducted at the same hospital that week on a patient named Myzoodeen. The concluding sentiment expressed in the article illuminates the unique parrhesiastic conundrum here, the equivocations that seem unavoidable while describing the truth-value of mesmerism. 
The anti-mesmerists must learn to see their wise words stultified by facts, and bear philosophically the idea of being laughed at by posterity; the mesmerists, on the other hand, must still be content to collect facts, and must leave to posterity the task of erecting theoretical structures. [....] We have no room to speak of the uses to which the peculiarity in mesmeric practice of which we have given some idea above, may be turned, but we may state that Dr. Esdaile has already made use of newly discovered power in dressing the wound of an young Oriah bearer who was operated on some time since. Among the persons present at the hospital on Saturday, we observed Mr. Halliday, Colonel Forbes, Dr. John Grant, Dr. Richard O'Shtiugnessy, and Mr. Humem. (Painless Operations 1848, 3)

Despite the correspondent's optimism regarding the value of mesmerism, he does not believe it will have a future until and unless it caters to the entertainment needs of the public. The truth of the mesmeric process is thus somehow tied up with the conditions of the performance of that truth to a body of people. In fact, the clinical integrity of the process, whether it exists or not, seems almost secondary to the need that it must appear flawlessly clinical and objective and unimpeachable at all costs.

In other words, mesmerism as a body of knowledge (provable only by observing its empirical effects, and in turn, by believing that the cause of those effects is the power of Nature itself) could be, in the mid-19th century, neither proved nor disproved with any sense of finality. This also meant that Esdaile's task here remains a work-in-progress with success always right around the corner, the epistemological robustness of his theory suspended for several years in a discursive purgatory of sorts. Each new surgical process successfully completely under the mesmeric influence appeared to bring him another step closer to recognition while at the same time he seemed to have not moved at all.

Esdaile is caught up in a certain ironic modality of truth-telling, a faux-parrhesia, the kind of utterance that belabours to prove its own truth value, and thereby extinguishes itself. By the nature of his repetitive attempts to prove mesmerism by empirical means, Esdaile's narrative never achieves the status of truth-telling. Rather, it remains interminably as truth that is yet to be proven true-to highlight another feature of faux-parrhesia here; the truth whose telling becomes interminably stabilised at the limits of medical discourse.

\section{"Like a Bengal Witness": Colonialism and Medical Faux-Parrhesia}

Waltraud Ernst speculates that one of the reasons for the eventual discrediting of Esdaile's surgical methods must be the fact that he performed them on natives whose testimonies and experiences were considered unreliable. The phrase "like a Bengal witness"-which appears quite unironically in the diary itself (Esdaile 1902, 35) —stood for unreliability or referred to someone likely to change their mind regarding what they saw. Prominent critics of Esdaile's practice in Hooghly also attacked the reliability of the subjects. However, the epistemological status of the native patient within the parrhesiastic game is far more complex than a matter of mere colonial prejudice.

Esdaile's own opinion about the suitability of the natives as ideal patients on whom to practice mesmerism is noteworthy. "The people of this part of the world seem to be peculiarly sensitive to the mesmeric power" Esdaile writes in his diary. Since they are a "feeble, ill-nourished race," it results in "a depressed state of the nervous system" which also, Esdaile proceeds to argue, ensures that they have "none of the morbid irritability of nerves, and the mental impatience of the civilized man" (Esdaile 1902, 25). The resultant passiveness of the patient is described thus: "neither thinking, questioning, nor remonstrating, but passively submitting to my pleasure, without in the smallest 
degree understanding my object or intentions" (Esdaile 25). Subsequently, in an almost anti-Cartesian turn of affairs, Esdaile wishes that the civilized European would "condescend to return for a moment" to this natural state of passivity and non-thought.

At first glance, this ethnographic description which conflates the medical status of the patient with racial identity resembles the early medical documents written in the Indian context by Englishmen around the time as Esdaile's practice in Hooghly such as Ranald Martin's severely prejudiced Notes on the Medical Topography of Calcutta (1837) which provides a wide-ranging account of the 'native' as a clinical/colonial subject. However, Esdaile's descriptions of the native patient inaugurates a complex narrative subjectivity that was not only a product of colonial discourse but also complicated the very terms of that discourse. In his above descriptions, for example, mesmerism appears to transcend racial identity and at the same time be severely defined by it. The ideal mesmeric subject is described both positively and negatively. The weakest qualities of the native patient are also what makes the native patient superior to the white man. But at the same time, paradoxically, there can be no doubt in the mind of the reader that the native patient is, in fact, a depleted version of the ideal white male. The codes of colonial discourse thus seem to have been unwittingly scrambled by Esdaile's description of the patient as an important cog in his elaborate truth-telling theatre of surgery.

Esdaile even goes a step further in this regard by drawing a familiar colonial equation between the native and the woman. "In choosing a proper subject," he writes in his diary, "I should probably have selected some highly sensitive female of a nervous temperament and excitable imagination." Instead, Esdaile remarks that he has been destined to work with "the worst specimen of humanity [...] a Hindoo felon of the hangman cast, condemned to labour on the road, in irons" (Esdaile 1902, 44). Both the woman and the native are ideal patients for the mesmeric process but yet, are not identical to each other. As we proceed further in the diary, other similar chains of false equivalence appears in the narrative, all of which seek to describe the ideal patient and the ideal doctor in comparative terms. ${ }^{\text {vii }}$

The same paradoxical formulation can be seen in the comparisons that Esdaile draws between mesmerism and similar indigenous methods of healing in Bengal that predated the arrival of English medicine. At one point, following an observation of how a local fuqueer cures a swollen knee with the help of his quasi-religious magical skills, Esdaile identifies all those so-called magical cures in India as healers practising mesmerism without an awareness of what they are doing (Esdaile 1902, 29). The foundational power being channelised by the fuqueer and the mesmeric practitioner is arguably the one and the same. However, that does not make the fuqueer and the mesmeric practitioner identical to each other in Esdaile's account. Similarity without identification thus becomes a regulating trope in his medical narrative.

The colonial subjects seem to be using, according to Esdaile, a deviant version of mesmerism, thus validating the universal claims of mesmerism but without legitimising the particular actors involved. In other words, the knowledge held by these charmers, while they practice mesmerism, is not mesmerism. As such, they are emblematic of the truth but they cannot tell the truth, nor can they be a parrhesiac as can Esdaile who identifies mesmerism with "jumbo-jumbo" and "black magic" (Esdaile 28) but does not equate the two or call them both the same. Similarly, when he addresses the fuqueer as a "brother magician" (29) in his diary, it is a pragmatic non-affiliation rather than genuine call for filiation because Esdaile does not consider himself to be a magician.

What happens to the native patient whose body is trapped in this parrhesiastic machine that Esdaile created in Hooghly? The patient is subjected to numerous intersecting gazes which are not only 
clinical in nature but also in continuation with the act of parrhesia. The patient-by being subjected to a series of questions before being mesmerised while under the trance and after the surgery has been successfully completed-participates in a circumlocutory fashion in the act of truth-telling in front of the State. The patient replies in front of an assembly of respectable witnesses, speaking in Bengalee while the native doctor translates back and forth.

The extreme passivity and ignorance of the native patient is recommended repeatedly by Esdaile as proving the much-needed stamp of authenticity to the medical performance. Convinced that the unwitting and passive character of his patients is proof that the experiment was not a con, and that there was no prior agreement between the doctor and the patient to put on an act, Esdaile records that he often mesmerized patients without their knowledge. He is also known to frequently conduct allegedly painless amputations while they were under the influence without seeking prior approval from the patients.

While medical ethics today would deem this an unpardonable offence, the uninformed state of the native patient is integral precisely in order to ensure that the truth could manifest itself for the public eye through the patient's body and words. Here, the staging of mesmeric testimony is clearly attempting to recreate the conditions of speaking under oath in front of the court of law. This parallelism of medical discourse with jurisprudence is further driven home by the episode recorded by Esdaile in his diary of a barber accused of kidnapping being tried in front of the judge. Esdaile appears as an expert witness against the accused by attesting in front of the judge that the kidnapped boy showed signs of having being put under the mesmeric influence by the barber (Esdaile 1902, 63-64). One of the important interventions made by Esdaile's text in medical discourse is thus the introduction of this intensified anxiety of truth-telling along with the specter of falsification.

Although the clinical episodes described by Esdaile are meant to instill faith in the reader about the mesmeric process, the epistemic status of the native patient in his parrhesiastic game continues to destabilize the text. The presence and absence of pain on the patient's body is to be witnessed by others, and this witnessing is based on the patient's words "Yes, it hurts" or "No, it hurts no more" (Esdaile 1902, 124). The patient's body is thus 'read' like a thermometer rather than like a text-it mechanistically denotes rather than signifying the truth. The keenest observers care less about the experience of pain than the existence of pain in the patient's body.

The patient's words, on the other hand,-the priceless verbal attestations-are simply an index of verifiability. They mean nothing until and unless the rest of the witnesses and supplementary witness (both European and native), repeatedly support it, until and unless other multiple patients attest to it. Without this supporting panoply of collective witnessing and attesting, the patient is an object of suspicion and not someone who can be trusted to embody the truth. The patient's words mean everything and at the same time mean nothing at all. The ideal subject of mesmerism is he who can describe what happened but without knowing what happened. It is the patient's absolute incapacity to articulate anything close to real knowledge that, ironically converts the patient into a carrier of knowledge. Thus, in many ways, Esdaile's patients represent an extraordinary configuration of the clinical/colonial subject. The figure of the native patient in his diary also turns on its head the contemporary figure of the informed patient in medical discourse.

\section{Conclusion: Beyond and Against the Cultural Logic of Parrhesia}

In his reading of parrhesia in the Greek play The Phoenician Women, Foucault points out that the Greek conception of parrhesia is tied to the idea of citizenship and the practice of slavery prevalent at the time. Thus, when Polyneices confides that the worst part of being exiled is the non-existence 
of the right to free speech, Jocasta exclaims "That is the slave's lot, not to speak one's thought" (Foucault 2019, 71) and this, according to Foucault, becomes one of the defining features of parrhesia-the distinction between those who have the right to parrhesia and those who don't have it. A slave will never assume the role of a parrhesiastes because a slave is not a citizen and only citizens can participate in the risky parrhesiastic game with the tyrant/ruler. The role of the native patient in Esdaile's diary is, by itself, an extreme example of truth-telling. It is also a colonial perversion of the lofty idea of parrhesia in general which, at best, exemplifies the ethos of democracy for the Greeks which the rest of the world have inherited through imperial channels of propagation.

Parrhesia is often linked to revolutionary figures and to democratic ideals in various commentaries about the concept in the recent past. It is identified as speech marked by the intensity of risky truthtelling to power. This illuminates several positive images of parrhesia in cultural studies. ${ }^{\text {viii }}$ As such, the relationship between courage and ignorance has been historically far less studied than the relationship between courage and knowledge and it is at this point that the concept of parrhesia requires further expansion. Esdaile's surgical diary reveals how a unique moment in colonial medical history becomes emblematic of a negative relationship with the parrhesiastic act. In Discourse and Truth, Foucault makes it clear that unique historical and literary examples help us to keep redefining what parrhesia is and what forms it can possibly take in interactions between the individual and the state. In other words, the chief characteristics of parrhesia remain an incomplete list.

Within the annals of medical history, especially in the 18th and 19th centuries when the clinical gaze was beginning to establish itself as the norm in the modern institutionalized practice of medicine, clinical documents such as Esdaile's diary exemplify the emergence of a difficult relationship between the historical subject and the desire to speak the truth. This results in an elaborate performative act that tries to approximate to parrhesia and is, more often than not, marked by its inability to attain that status. Thus, arguably, the failure to accomplish the role of the parrhesiastis is also a part of the history of parrhesia. The perversion of truth-telling that takes place in the context of colonialism and clinical science in Esdaile's diary becomes a critique of parrhesia precisely at those points in history when it spectacularly fails to materialise.

\section{Notes}

${ }^{\text {i }}$ See, for example, the short story "The Facts in the Case of M. Valdemar" by Edgar Allan Poe as well as O. Dell's paper "The Facts in the Case of M. Valdemar': Undead Bodies and Medical Technology" (2020) on the literary lineage that can be traced between Edgar Allan Poe and Franz Mesmer.

ii Another minor but notable example is the case of Joseph Johnstone, a British doctor practising in Madras in the 19th century. Inspired by the stories of Esdaile's successful mesmeric surgeries in Hooghly, Johnstone reportedly excised a large, soft tumour from the back of a woman successfully, using mesmerism. To this day, the best performing student in the Madras Medical School receives "The Johnstone Medal 1848" (Raman \& Raman 2019).

iii The first edition of the diary came out in 1846. It was published in London by Longman, Brown, Green and Longman's and was titled Mesmerism in India, and its Practical Application in Surgery and Medicine. In 1852, another book appears authored by Esdaile, published by Hippolyte Bailliere, titled Natural and Mesmeric Clairvoyance, with the Practical Application of Mesmerism in Surgery and Medicine. Lastly, in 1902, the first 
book reappears in Chicago, published this time by The Psychic Research Company invested in establishing the truth of psychic phenomena.

iv This equating of the 'fraud' of mesmerism with that of homeopathy appeared in the Medical Times in 1851. It is quoted by Esdaile himself in the ironic yet poignant section titled "To the Members of the Medical Profession" which appears as a Preface to his book titled The Introduction of Mesmerism (With the Sanction of the Government) into the Public Hospitals of India (1856).

${ }^{v}$ In fact, the Lancet went as far as to proclaim in 1848 that they will not publish any paper on the subject of "such an odious fraud as mesmerism" (Esdaile 1856, 8).

${ }^{v i}$ A copy of this article which appeared in the Bengal Hurkaru was republished shortly afterwards in The Sydney Morning Herald on March 7th, 1848, under the category "Miscellaneous Extracts. Painless Operations." A digital copy of this newspaper article is available online at https://trove.nla.gov.au/newspaper/article/12896454.

vii The cast of patients who troop into Esdaile's clinic is, in reality, more diverse as we can see from his diary entries. "May 5th- Rantoonee Buttachangie, a Brahmin; ages 40," writes Esdaile. "There is a prodigious Fungus haematodes protruding from the left elbow-joint." Similarly, the logging continues; "May 11th — Podoo, a young Hindoo woman, has a swelling over the false ribs of the right side, requiring an incision to be made in it." This is followed by "a Musalmann" and later a "coolie." Age, profession, caste, and religion are mentioned by Esdaile in each of these entries but not systematically. If Esdaile mentions caste in one entry, he mentions only the profession in another entry, and religion in the third. Thus, while the document could have been quite a compendium of colonial medical ethnography, it was also unhelpfully homogenized by Esdaile's obsession with the category of "native patient" over and above their distinctive local social identities.

viii See Weiskopf \& Tobias-Miersch (2016) and Anderson (2019) for an illustrative example of this mode of analysis.

\section{References}

Anderson, A. (2019). "Parrhesia: Accounting for different contemporary relations between risk and politics," Journal of Sociology 55(3), 495-510. https://doi.org/10.1177/1440783319829245, accessed February $10,2021$.

Armando, D. \& Belhoste, B. (2018). "Mesmerism between the end of the Old Regime and the Revolution: Social dynamics and political issues," in Annales historiques de la Révolution française, 1(1), 3-26. https://www.cairn-int.info/journal-annales-historiques-de-la-revolution-francaise-2018-1-page-3.htm, accessed February 1, 2021.

Darnton, R. (1970). "Mesmerism and popular science," in Mesmerism and the end of the enlightenment in France, 2-45. Harvard University Press.

Ernst, W. (1995). “Under the influence 'in British India: James Esdaile's Mesmeric Hospital in Calcutta, and its critics." Psychological Medicine, 25(6), 1113-1123. https://doi.org/10.1017/So033291700033092, accessed October 5, 2020.

Esdaile, J., (1852). "Preface," in Natural and Mesmeric Clairvoyance, with the Practical Application of Mesmerism in Surgery and Medicine, v-xiii. Hippolyte Bailliere.

Esdaile, J., (1856). “To the Members of the Medical Profession," in The Introduction of Mesmerism (With the Sanction of the Government) into the Public Hospitals of India (2nd Ed), 5-11. W. Kent and Co.

Esdaile, J., (1902) Mesmerism in India, and its Practical Application in Surgery and Medicine. The Psychic Research Company.

Flower, Sydney. (1902) "Preface," in Esdaile, J. (Ed), Mesmerism in India, and its Practical Application in Surgery and Medicine. The Psychic Research Company. 
Foucault, Michael. (1973; 2003) The birth of the clinic: An archaeology of medical perception. (A. M. Sheridan, Trans.). Tavistock Publications.

Foucault, M., Fruchaud, H.-P., Lorenzini, D., \& Luxon, N. (2019). Discourse and truth and Parrēsia. University of Chicago Press.

Lamont, P. (2013). "The making of mesmeric phenomena," in Extraordinary beliefs: A historical approach to a psychological problem, 63-125. Cambridge University Press. doi:10.1017/CBO9781139094320.004, accessed on February 3, 2021.

Martin, J. R. (1837). Notes on the medical topography of Calcutta. G.H. Huttmann.

O'Dell, S. (2020). "The Facts in the Case of M. Valdemar: Undead Bodies and Medical Technology." J Med Humanit 41, 229-42. https://doi.org/10.1007/s10912-019-09574-w, accessed on January 2, 2021.

Painless Operations. (1848, 7 March) The Sydney Morning Herald. https://trove.nla.gov.au/newspaper/article/12896454, accessed on August 15, 2020.

Pattie, F.A. (1994). Mesmer and animal magnetism: A chapter in the history of medicine. Edmonston Publishing.

Raman, R., \& Raman, A. (2019). "A Painless Surgery Joseph Johnstone Performed on a Mesmerized Patient in Madras in 1847." Indian Journal of History of Science, 54.1, 13-22. DOI: 10.16943/ijhs/2019/v54i1/49594, accessed August 12, 2020.

Rosen, G. (1946). "Mesmerism and Surgery: A strange chapter in the history of anesthesia." Journal of the History of Medicine and Allied Sciences, 1(4), 527-550.

W[ebb?], A[llan]. (1846, 4 June) Correspondence. Letter to the Editor. The Bengal Hurkaru and India Gazette.

Weiskopf, R., \& Tobias-Miersch, Y. (2016). "Whistleblowing, Parrhesia and the Contestation of Truth in the Workplace.” Organization Studies, 37(11), 1621-1640. https://doi.org/10.1177/o170840616655497, accessed on February 8, 2021.

Willis, M., \& Wynne, C. (2006). “Introduction," in Victorian literary mesmerism, 1-16. Rodopi. 